\title{
Personalized prostate cancer diagnosis and treatment-are we ready?
}

\author{
Isabel Heidegger
}

Prostate cancer (PCa) is the most common cancer in men and one of the leading causes of death [1]. In general, PCa varies from slow-growing indolent tumors to highly aggressive tumors associated with disease-related morbidity and mortality [2].

The use of prostate-specific antigen (PSA) for early detection of PCa has contributed to a favorable shift in tumor stage at diagnosis resulting in decreased PCa morbidity and mortality [3-5]. Despite this, PSA screening is one of the most controversial topics in urology as numerous tumors are low-risk cancers that probably never become aggressive.

In the past years, beside PSA measurement, multiparametric magnetic resonance imaging (MRI) has proven clinical efficacy in PCa detection [6].

Steinkohl et al. present the latest findings concerning a new technique in PCa detection denoted by "biparametric prostate MRI." In contrast to multiparametric MRI protocols, biparametric MRI does not include dynamic contrast-enhanced sequences, thus having major advantages compared with the conventional prostate MRI such as shorter examination time, lower costs, or reduction of contrast-agent-based side effects.

Although most PCa are adenocarcinomas, there also exist histologically heterogeneous PCas including different forms of neuroendocrine carcinomas associated with poor clinical outcome. Tsaur et al. elaborately explain the tumor biology of these cancers and highlight the potential role of biomarkers in this rare disease. In addition, optimal treatment is discussed proposing cisplatin/etoposide chemotherapy in pure cell neuroendocrine PCa, while a taxane/

\section{Heidegger $(\bowtie)$}

Department of Urology, Medical University of Innsbruck,

Anichstraße 35, 6020 Innsbruck, Austria

Isabel-maria.heidegger@i-med.ac.at platinum-based regimen should be administered in neuroendocrine carcinoma/acinar adenocarcinoma.

Oligometastatic PCa has been considered an intermediate state between localized disease and widespread metastases mostly defined as up to five extrapelvic lesions [7, 8]. While until several years ago these patients were treated only with hormonal therapy, in the past few years the concept of multimodal treatment has evolved. Bektic et al. give a state-of-theart overview of current data on the role of surgery in oligometastatic PCa and critically discuss advantages and disadvantages of this future-oriented treatment concept.

Lataly the landscape of treatment for patients with metastatic castration-resistant PCa has substantially changed including new hormonal therapies (abiraterone, enzalutamide), chemotherapies, or radium223 [9, 10]. Lutetium-prostate-specific membrane antigen (Lu-PSMA) therapy is an additional new therapeutic treatment option in metastatic castrationresistant $\mathrm{PCa}$. Although data from phase III studies are not yet mature, phase II data indicate promising treatment responses accompanied by a good safety profile, as illustrated by the review article from Ladurner and colleagues [11].

One of the hot topics in current research is the gut microbiome, as novel findings provide new options to facilitate earlier diagnosis as well as to improve the efficacy of chemotherapy or immunotherapy by selective manipulation of the gut microbiota [12]. Strasser and colleagues give a comprehensive overview of the existing literature on the microbiome of $\mathrm{PCa}$, thereby demonstrating that differences in the microbial composition analyzed in urine, prostate tissue, and feces as well as microbial metabolites seem to also be involved also in the pathogenesis of PCa. In addition, the authors underline that androgen-deprivation therapy may interfere with the intestinal microbiome. 
Conflict of interest I. Heidegger declares that she has no competing interests.

\section{References}

1. Siegel RL, Miller KD, Jemal A. Cancer statistics, 2017. Ca Cancer JClin. 2017;67:7-30.

2. Mottet N, Bellmunt J, Bolla M, Briers E, Cumberbatch MG, De Santis M, Fossati N, Gross T, Henry AM, Joniau S, Lam TB, Mason MD, Matveev VB, Moldovan PC, van den Bergh RCN, Van den Broeck T, van der Poel HG, van der Kwast TH, Rouviere O, Schoots IG, Wiegel T, Cornford P. EAU-ESTROSIOG guidelines on prostate cancer. Part 1: screening, diagnosis, and local treatment with curative intent. Eur Urol. 2017;71:618-29.

3. Bartsch G, Horninger W, Klocker H, Pelzer A, Bektic J, Oberaigner W, Schennach H, Schafer G, Frauscher F, Boniol M, Severi G, Robertson C, Boyle P, Tyrol Prostate Cancer Screening Group. Tyrol prostate cancer demonstration project: early detection, treatment, outcome, incidence and mortality. Cancer. 2008;101:809-16.

4. Phillips R. Prostate cancer: PSA update-no changeyet. Nat RevUrol. 2014;11:483.

5. Schroder FH, Hugosson J, Roobol MJ, Tammela TL, Zappa M, Nelen V, Kwiatkowski M, Lujan M, Maattanen L, Lilja H, Denis LJ, Recker F, Paez A, Bangma CH, Carlsson S, Puliti D, Villers A, Rebillard X, Hakama M, Stenman UH, Kujala P, Taari K, Aus G, Huber A, van der Kwast TH, van Schaik RH, de Koning HJ, Moss SM, Auvinen A, Investigators E. Screening and prostate cancer mortality: results of the European Randomised Study of Screening for Prostate Cancer (ERSPC) at 13 years of follow-up. Lancet. 2014;384:2027-35.

6. Thompson J, Lawrentschuk N, Frydenberg M, Thompson L, Stricker P, USANZ. The role of magnetic resonance imaging in the diagnosis and management of prostate cancer. BJU Int. 2013;112(Suppl2):6-20.

7. Gillessen S, Attard G, Beer TM, Beltran H, Bossi A, Bristow A, Carver B, Castellano D, Chung BH, Clarke N, Daugaard G, Davis ID, de Bono J, Borges Dos Reis R, Drake CG, Eeles R, Efstathiou E, Evans CP, Fanti S, Feng F, Fizazi K, Frydenberg M, Gleave M, Halabi S, Heidenreich A, Higano
CS, James N, Kantoff P, Kellokumpu-Lehtinen PL, Khauli RB, Kramer G, Logothetis C, Maluf F, Morgans AK, Morris MJ, Mottet N, Murthy V, Oh W, Ost P, Padhani AR, Parker C, Pritchard CC, Roach M, Rubin MA, Ryan C, Saad F, Sartor O, Scher H, Sella A, Shore N, Smith M, Soule H, Sternberg CN, Suzuki H, Sweeney C, Sydes MR, Tannock I, Tombal B, Valdagni R, Wiegel T, Omlin A. Management of patients with advanced prostate cancer: the report of the advanced prostate cancer consensus conference APCCC 2017. Eur Urol. 2018;73:178-211.

8. Tilki D, Pompe RS, Bandini M, Marchioni M, Kretschmer A, Tian Z, Karakiewicz PI, Evans CP. Local treatment for metastatic prostate cancer: a systematic review. Int J Urol. 2018;25:390-403.

9. Heidegger I, Heidenreich A, Pfister D. New biomarkers for selecting the best therapy regimens in metastatic castration-resistant prostatecancer. TargetOncol. 2017;12:37-45.

10. Heidegger I, Massoner P, Eder IE, Pircher A, Pichler R, Aigner F, Bektic J, Horninger W, Klocker H. Novel therapeutic approaches for the treatment of castration-resistant prostate cancer. J Steroid Biochem Mol Biol. 2013;138:248-56.

11. Hofman MS, Violet J, Hicks RJ, Ferdinandus J, Thang SP, Akhurst T, Iravani A, Kong G, Kumar AR, Murphy DG, Eu P, Jackson P, Scalzo M, Williams SG, Sandhu S. [(177)Lu]-PSMA-617 radionuclide treatment in patients with metastatic castration-resistant prostate cancer (LuPSMA trial): a single-centre, single-arm, phase 2 study. lancet Oncol. 2018;19:825-33.

12. von Frieling J, Fink C, Hamm J, Klischies K, Forster M, Bosch TCG, Roeder T, Rosenstiel P, Sommer F. Grow with the challenge-microbial effects on epithelial proliferation, carcinogenesis, and cancer therapy. Front Microbiol. 2018;9:2020.

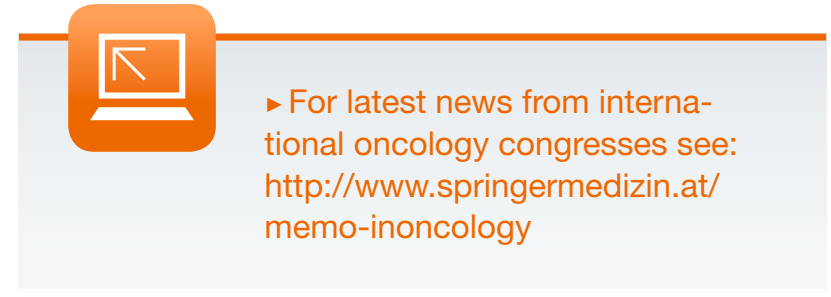

